\title{
Inflation Targeting by Debtor Central Banks in Emerging Market Economies
}

\author{
Axel Löffler \\ Gunther Schnabl \\ Franziska Schobert
}

\author{
CESIFO WORKING PAPER NO. 3138 \\ CATEGORY 7: MONETARY POLICY AND INTERNATIONAL FinANCE \\ JULY 2010
}
An electronic version of the paper may be downloaded
- from the SSRN website: www.SSRN.com
- from the RePEc website: $\quad$ www.RePEc.org
- from the CESifo website: www.CESifo-group.org/wp




\title{
Inflation Targeting by Debtor Central Banks in Emerging Market Economies
}

\begin{abstract}
Given buoyant capital inflows and managed exchange rates the majority of emerging market central banks have continued to accumulate massive foreign reserves. If left unsterilized, the liquidity expansion can threaten domestic macroeconomic stability. To contain domestic inflation these central banks absorb rather then provide liquidity in their regular monetary policy operations. Based on an augmented Barro-Gordon framework we show that inflation targeting within an environment of surplus liquidity is less efficient, because absorbing liquidity raises the costs of monetary policy operations. By implementing sterilization costs into the central bank's objective function the inflation bias increases.
\end{abstract}

JEL-Code: E52, E58.

Keywords: inflation targeting, exchange rate targeting, sterilization, debtor central bank.

\author{
Axel Löffler \\ Leipzig University \\ Grimmaische Strasse 12 \\ Germany-04109 Leipzig \\ loeffler@wifa.uni-leipzig.de
}

\author{
Gunther Schnabl \\ Leipzig University \\ Grimmaische Strasse 12 \\ Germany - 04109 Leipzig \\ schnabl@wifa.uni-leipzig.de
}

\author{
Franziska Schobert \\ Deutsche Bundesbank \\ Wilhelm Epstein-Strasse 14 \\ Germany - 60431 Frankfurt \\ franziska.schobert@bundesbank.de
}

Version: 20 July 2010

Any remaining errors are those of the authors. The findings, interpretations and conclusions do not necessarily represent the views of the Deutsche Bundesbank. 


\section{Introduction}

During the recent post-crisis recovery the emerging markets and developing countries continue to face challenges in monetary policy making. In the large industrial countries interest rates have reached historical lows and the exit from unorthodox monetary policies keeps being postponed as the economic recovery remains sluggish. At the same time growth perspectives in the emerging markets have strengthened. The outcome has been an unprecedented surge in carry trades, which originate in the large financial markets and hunt for yield in the underdeveloped financial markets of emerging market economies.

The buoyant influx of hot money into the emerging markets poses major problems for monetary policy making. Most emerging markets fear an appreciation of their exchange rates above levels which they regard as appropriate for export competitiveness and growth. The result has been fast rising foreign reserves on a global level. If left unsterilized, reserve accumulation is equivalent to liquidity expansion that threatens domestic macroeconomic stability. Therefore, central banks sterilize surplus liquidity in different ways (Schnabl and Schobert 2009) and thereby face trade-offs: Market-oriented monetary policy operations can become costly and attract new hot money inflows. Non market-oriented alternatives contain sterilization costs and reduce new capital inflows, but lead to distortions in the domestic financial system.

For these - and other reasons - emerging markets have been advised to release their exchange rate pegs and to introduce inflation targeting frameworks to conduct market-based monetary policy operations with money market interest rates as the operational target (Fischer 2000). Inflation targeting (IT) frameworks have been perceived as successful in many industrialized economies (Bernanke et al 1999, McCallum 1996, Leiderman and Svensson 1995, Ball and Sheridan 2005) and have been recommended for emerging market economies (Rose 2007). The arguments in favour of an IT framework usually focus on the benefits of an autonomous monetary policy that is able to address country-specific shocks based on the objective of internal price (and output) stability. IT regimes are argued to be transparent as they can be clearly communicated to the public and thereby provide an anchor for inflation expectations (Svensson 1997). 
Although the structural challenges to implement an IT framework in emerging markets are recognized (Calvo and Mishkin 2003, Mishkin 2004, Fraga et al. 2003, Roger 2009) the discussion on inflation targeting in emerging markets usually overlooks an important issue: Many central banks in emerging market economies conduct monetary policy within an environment of surplus liquidity. Even if they aim to fully switch from exchange rate targeting to an autonomous monetary policy, surplus liquidity will persist. This will be a drag on independent monetary policy making, as IT within an environment of surplus liquidity can have substantial costs which make a binding inflation target less credible. Based on an augmented Barro-Gordon framework we will argue that IT in emerging markets with central banks facing considerable surplus liquidity is less efficient than in large industrial countries.

\section{Asymmetric Monetary Policies}

While the monetary policies of countries with international currencies (US, euro area) aim exclusively on domestic targets, the countries at the periphery of the large currency blocks tend to respond to external targets by stabilizing exchange rates (McKinnon 2004, McKinnon and Schnabl 2009). In recent years up to and after the current financial and economic crisis many periphery countries were/are facing buoyant foreign exchange inflows and appreciation pressure on their domestic currencies. The central banks accumulate fast rising stocks of foreign assets as shown in Figure 1, which are the most important reason for creating or enlarging the liquidity surplus in the domestic financial systems (Schnabl and Schobert 2008).

Figure 1: Global Foreign Exchange Reserves, Jan 1990 - Dec 2009

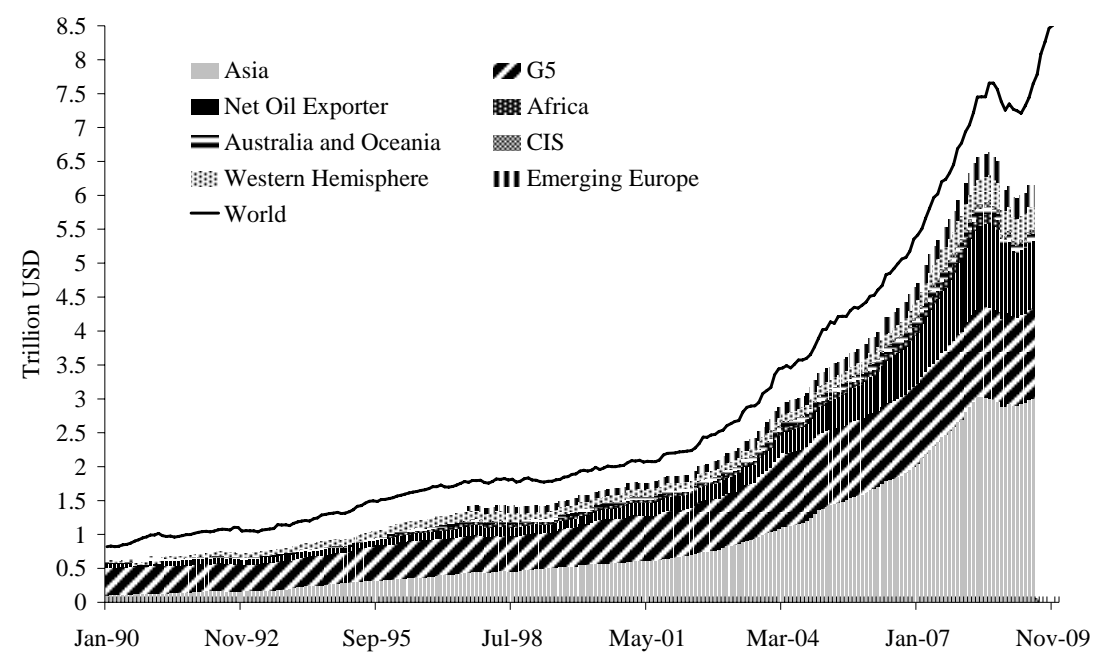

Source: IFS. 
This reflects the asymmetry of the world monetary system. Whereas monetary authorities of the US and euro area have the privilege to provide scarce liquidity to the domestic banking system by conducting (net) monetary policy operations on the asset side of their balance sheets, most periphery central banks are liquidity absorbing on a structural basis. (Net) monetary policy operations take place on the liability side of the balance sheets.

\subsection{Creditor vs. Debtor Central Banks}

Creditor central banks independently conduct monetary policy by steering domestic interest rates with liquidity-providing operations. The Eurosystem and the Federal Reserve System mainly conduct open market operations to provide liquidity to the financial system. These open market operations take place on the asset side of the central bank balance sheet either via outright purchases of domestic bonds or via reverse transactions. The volume of open market operations on the asset side increases with the expansion of currency in circulation (CIC) on the liability side. Changes in net foreign assets (NFA) are small and mainly driven by valuation changes as the exchange rate is floating.

In contrast, the causality in monetary policy operations by debtor central banks tends to be reverse. Monetary policy operations by what we call debtor central banks tend to react to exchange rates which play a dominant role for monetary policy making. Autonomy in monetary policy making is limited due to open capital accounts and exchange rate targeting (impossible trinity). In an environment of buoyant capital inflows and exchange rate stabilization debtor central banks have to absorb surplus liquidity to keep control over domestic interest rates and inflation. This is reflected in central bank balance sheets. Foreign reserves are the dominant item on the asset side of the balance sheet, which necessitates monetary operations on the liability side to contain inflation.

\section{Defining Surplus Liquidity}

The stylized central bank balance sheet as shown in Table 1 helps to define liquidity creation and absorption in the domestic banking system ${ }^{1}$. (Net) foreign assets (item 1) mainly include foreign reserves, which normally originate in foreign exchange intervention. ${ }^{2}$ Item 2 summarizes domestic assets that are held for different purposes, e.g. for monetary policy reasons (item 2.1.1 and 2.2.1), such as liquidity providing open market operations or standing

\footnotetext{
${ }^{1}$ For simplicity, the term "banks” summarizes monetary financial institutions.

${ }^{2}$ In the following we assume for parsimony reasons that NFA are exclusively held in form of foreign reserves.
} 
facilities), for investment purposes, for financial stability considerations, or for financing the government and/or public entities.

On the liability side the monetary base (item 3) includes CIC and reserve holdings of commercial banks at the central bank. Deposits of deposit money banks, i.e. reserves of banks (item 3.2) consist of required reserves and excess reserves. Excess reserves (item 3.2.2) are determined "exogenously" by the commercial banks, reserve requirements (item 3.2.1) are determined by the central bank, possibly as monetary policy tool. Item 4 are government deposits held at the central bank (see sections 2.3 and 3.3). Item 5.1 and item 6 include liquidity absorbing monetary policy operations such as reverse repos or central bank bond sales. Item 7 (capital accounts) represents the own funds of the central bank. Liquidity, here defined as excess reserves (item 3.2.2), can increase if ceteris paribus items on the asset side grow or items on the liability side (apart from liquidity itself) shrink.

Table 1: Stylized Central Bank Balance Sheet

\begin{tabular}{l|l}
\hline Assets & Liabilities \\
\hline 1. (Net) Foreign Assets (NFA) & 3. Monetary Base \\
& 3.1 Currency in Circulation (CIC) \\
& 3.2 Deposits of banks \\
& 3.2 .1 Required reserves \\
& 3.2 .2 Excess reserves \\
\hline 2. Domestic Assets & 4. Government deposits \\
2.1 Securities & 5. Liabilities to banks \\
2.1.1 Securities held for & 5.1 Related to monetary policy \\
monetary policy purposes & operations** \\
2.1.2 Other securities & 5.2 Others \\
2.2 Lending to banks & 6. Debt securities issued \\
operations* & \\
2.2 .2 Others & \\
\hline
\end{tabular}

Note: * Liquidity providing i.e. open market operations (collateralized lending, repos) or standing lending facility. ** Liquidity absorbing i.e. open market operations (auctioned deposits, reverse repos) or standing deposit facility. 
Because excess reserves earn either no or an interest rate below the interbank rate, commercial banks under usual conditions attempt to minimise excess reserve holdings. Also central banks aim at a minimum natural level of excess reserves that depends on the liquidity conditions and risk considerations of commercial banks. If the supply of liquidity exceeds demand for liquidity, commercial banks tend to lend their excess funds in the overnight market, putting downward pressure on the interbank rate. Declining interest rates can nurture excessive credit growth, inflation and overheating. To control interest rates in the money market, the central bank can transform excess reserves (3.2.2.) into required reserves (item 3.2.1) or offer an alternative investment opportunity, for instance by selling central bank bonds at market rates as market-oriented sterilization (5.1).

A liquidity deficit or surplus of the banking system vis-à-vis the central bank can be identified based on so called 'autonomous factors'. Bindseil (2005: 46) and the European Central Bank (2001: 42) define autonomous factors as factors that are outside the control of the central bank, i.e. that are not the result of monetary policy operations or excess reserves (liquidity) of commercial banks with the central bank. Monetary policy operations in this definition reflect the decision making of the central bank that aims at domestic price stability. In this context, foreign exchange intervention is regarded as an autonomous factor as it aims at other objectives, for instance, at a more competitive exchange rate to sustain growth.

Defining autonomous factors can be ambiguous. For instance, the question of whether changes in domestic assets should be regarded as autonomous factors depends on the motivation of the transaction. If, for example, security purchases are decided by the central bank independently to steer interest rates with the ultimate objective to control inflation, they can be regarded as monetary policy operations. ${ }^{3}$ If, however, securities are acquired by coercion to finance government expenditure or to bail out private entities in the case of crisis, ${ }^{4}$ changes in domestic assets can be regarded as autonomous. ${ }^{5}$ Distinguishing monetary policy operations from government financing or the financial system bailouts requires detailed

3 For example the Federal Reserve System (FED) traditionally has conducted open market operations by outright purchases of domestic government bonds.

4 During the recent financial crisis the balance sheets of large creditor central banks have been expanded in the context of quasi bailout operations. This has raised questions concerning liquidity absorption also for creditor central banks.

5 In the Eurosystem, for example, purchases of government securities on the primary market are regarded as government financing. EC council regulation 3603/93 stresses that purchases on the secondary market should not circumvent the prohibition of public financing by the central bank. 
information concerning the motivation of the respective transaction and is therefore a matter of transparency of the central bank (Schobert 2006).

On the liability side, currency in circulation is defined as an autonomous factor, because it is determined exogenously by the currency demand of the private sector. Government deposits at the central bank (item 4) can be regarded as an autonomous factor if they are determined by the government without consultation with the central bank. They can, however, also reflect (quasi) monetary policy operations that are conducted in coordination with the fiscal authorities at the initiative of the central bank (section 2.3).

A structural liquidity surplus can persist for many years after monetary policy has become autonomous and the accumulation of foreign reserves has stopped, as CIC is the most important liquidity absorbing factor. Currency demand usually only grows gradually, for instance linked to economic growth or even by less if there are changes in payment habits that reduce the use of cash. If, for instance net foreign assets are twice as high as the outstanding stock of currency, and currency grows with a rate of 5\% p.a., the surplus liquidity created by the past accumulation of net foreign assets ceteris paribus will be only eliminated after about 14 years.

\subsection{Sources of Surplus Liquidity}

There are three main reasons (autonomous factors) for surplus liquidity. (1) Exchange rate stabilization, i.e. the accumulation of net foreign assets (NFA), (2) fiscal (or quasi-fiscal) financing, i.e. the accumulation of public debt, and (3) restructuring after financial crises as usually reflected in an increase of claims to the banking sector and/or the public sector. Whereas (2) has become a less frequent source (as central banks have gained more independence in emerging market economies), (3) can become important after financial crises. As (3) has been limited in most emerging market economies after the most recent crisis, (1) remains currently the dominating source of surplus liquidity in these economies. This is even more the case, as interest rates in large financial markets have reached historical lows and capital inflows and reserve accumulation in emerging markets have accelerated again. 
The ratio of net foreign assets (NFA) to currency in circulation (CIC) can be used to approximate surplus liquidity within an environment where liquidity creation is dominantly driven by reserve accumulation. Whereas domestic assets can reflect both, autonomous factors or monetary policy operations, NFA are clearly autonomous as they originate in exchange rate operations rather than monetary policy operations. If on the liability side the most important autonomous liquidity absorbing item is CIC, surplus liquidity originating in foreign reserve accumulation can be approximated by comparing NFA on the asset side with CIC on the liability side. Assuming that there are no other substantial liquidity-absorbing autonomous factors on the liability side of the balance sheet, a ratio above 1 indicates a debtor position of a central bank, i.e. surplus liquidity of the banking system.

Figure 2 shows that surplus liquidity as approximated by the ratios of NFA to CIC is a worldwide phenomenon. Based on a sample of 150 central bank balance sheets Figure 2 provides information of how foreign exchange accumulation contributed to surplus liquidity in different world regions over time. The vertical axis indicates the average NFA-CIC-ratio for the years 1990-2000 and the horizontal axis for the average of the years 2001-2009. ${ }^{6}$ Central banks within the shaded area have NFA-CIC-ratios smaller than one which indicates a moderate accumulation of foreign reserves. Assuming that there are no other sources of surplus liquidity, these central banks can operate within an environment of a liquidity deficit.

A ratio larger than unity indicates, based on the underlying definition, that foreign reserve accumulation has created a structural liquidity surplus and the central bank has a debtor status towards the domestic financial system. Comparing the periods before and after 2000 an increasing number of central banks have moved deeper into the debtor status as indicated by the cluster above the $45^{\circ}$-diagonal. Whereas in the years before 2000 still a considerable number of emerging market central banks were below the unity-benchmark, in the years after 2000 almost all have moved clearly into the debtor position. Calculated as the ten-year average $^{7}$ from 1990-2000 79 out of 150 central banks were in a foreign reserve based debtor position, in the period from 2001-2009 118 of 150 central banks are classified as debtor central banks. This finding is independent from the country group. In contrast, the US Fed and the European Central Bank (as most important creditor central banks) did not change their creditor central bank status.

\footnotetext{
${ }^{6}$ Negative values indicate higher foreign liabilities than foreign assets.

${ }^{7}$ Or the average of the years with data available.
} 
Figure 2: NFA/CiC Ratio of 150 Central Banks, 1990-2008

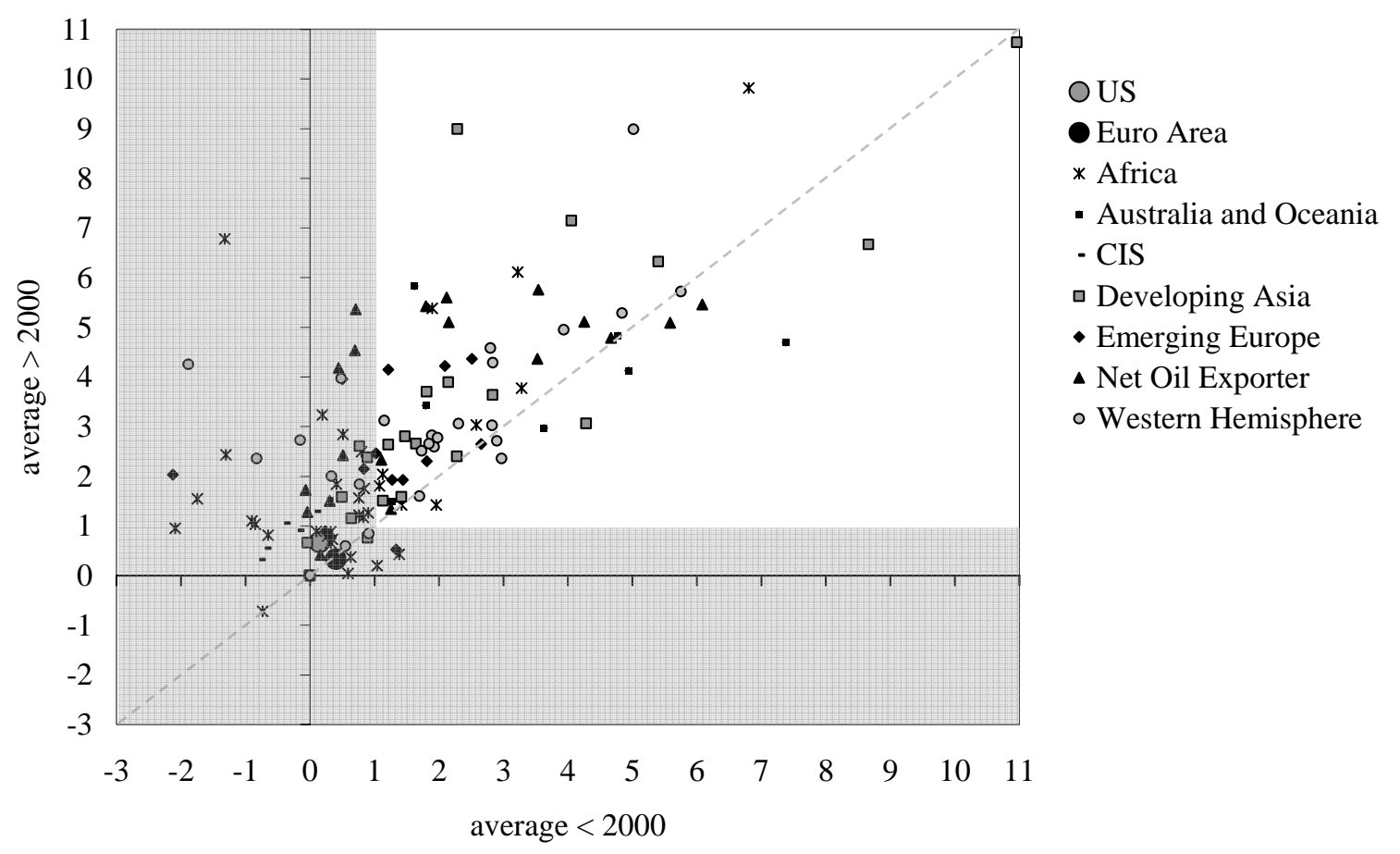

Source: IFS, National Central Banks.

\subsection{Managing Surplus Liquidity}

Central banks have three options to manage the surplus. (1) They can absorb liquidity by using market-oriented monetary policy operations, i.e. open market operations, standing facilities or reserve requirements that are remunerated at market rates. Market based sterilization is effective in steering interest rates. But it is costly, because the central bank has to compete with other investment opportunities of the banking system. (2) Less expensive, but distortionary to the domestic financial system is the implementation of non-market based measures, for example, minimum reserve requirements with no or low remuneration or the coercive sale of central bank securities below market rates. (3) There is fiscal coordination, which can take place under two preconditions. First, if the central bank stores foreign exchange on behalf of the government. This is most prominent in case of oil-exporting countries, where the government either owns the exported natural resources or taxes their export revenues. The government can agree to hold the revenues on its account with the 
central bank. The "sovereign wealth" will have no liquidity providing effect, as long as it is saved at the central bank account and not spend in the domestic market. ${ }^{8}$

Second, if the central bank has bought foreign exchange from the private sector, the operation will be liquidity providing to the domestic banking system. The fiscal authorities can agree to issue and sell more government securities than necessary to cover the budget deficit. The revenues from the excess issuance can be held as government deposits at the central bank. In this case, government deposits are quasi-monetary policy operations, as long as the central bank is able to control withdrawals. Conflicts of interest may arise between government debt management and monetary policy if the interest rate on government securities and the withdrawal of deposits by the government is not in line with the monetary policy targets of the central bank.

We provide information how the structure of sterilization instruments has changed over time. For this purpose, we first calculate the ratio of NFA to CIC for all countries and exclude the countries and years, which do not fulfill the debtor central bank criterion due to the accumulation of foreign assets (NFA-CIC-ratio below unity). For the remaining countries (114 central banks) we exclude that domestic assets reflect monetary policy operations, as this would further increase surplus liquidity in the banking system. ${ }^{9}$ Thus, by assuming that domestic assets are an autonomous factor which additionally creates surplus liquidity, we can estimate the total sterilization needs for these central banks by calculating the total financing gap as the sum of NFA and domestic assets minus the sum of CIC and the capital of the central bank.

The total financing gap can be absorbed by market oriented or non-market oriented sterilization operations or it can be managed by fiscal coordination. These three sterilization tools are shown as shares of the total financing gap in Figures 3 to 5. In Figure 3 the share of open market operations in the total financing gap approximates the importance of marketoriented sterilization and its change over time. Open market operations are proxied by debt securities issued by the central bank and other central bank liabilities to the banking system

8 Alternatively the oil revenues are stored directly in a dollar denominated sovereign wealth fund. As foreign reserves are prevented at the roots from being converted into domestic currency, a sovereign wealth fund corresponds to "anticipatory sterilization".

$9 \quad$ In practice, liquidity providing and liquidity absorbing monetary policy operations can be conducted at the same time, if the interbank market is not working efficiently. In some cases operations provide liquidity to some banks, even though there is already ample liquidity on aggregate. This can reflect bail-out operations. 
apart from bank deposits. ${ }^{10}$ For most central banks the share ranges between $0 \%$ and $20 \%$. A large number of entries is close to zero which implies that market-oriented sterilization is comparatively rare. Over time a slightly increasing number of debtor central banks seem to have switched from non-market based to market-oriented sterilization operations as comparatively few central banks are under the diagonal. The whole sample average share of open market operations on the total financing gap increased from 8 to 12 percent comparing the period from 1990 to 2000 with the period from 2001 to 2008.

In Figure 4 bank deposits as a share of the total financing gap approximate the importance of non-market oriented sterilization operations. Excess reserves are assumed zero so that bank deposits can be used as a proxy for required reserves. Given the assumption that required reserves are usually not remunerated or remunerated below market rates, they can be seen as a proxy for non-market oriented sterilization. As indicated by the pattern in Figure 4 this instrument is widely used by debtor central banks. The whole sample average of required reserves on the total financing gap is widely unchanged over the time dimension (36 to 35 percent).

Figure 3: Share of Market Operations in the Total Financing Gap

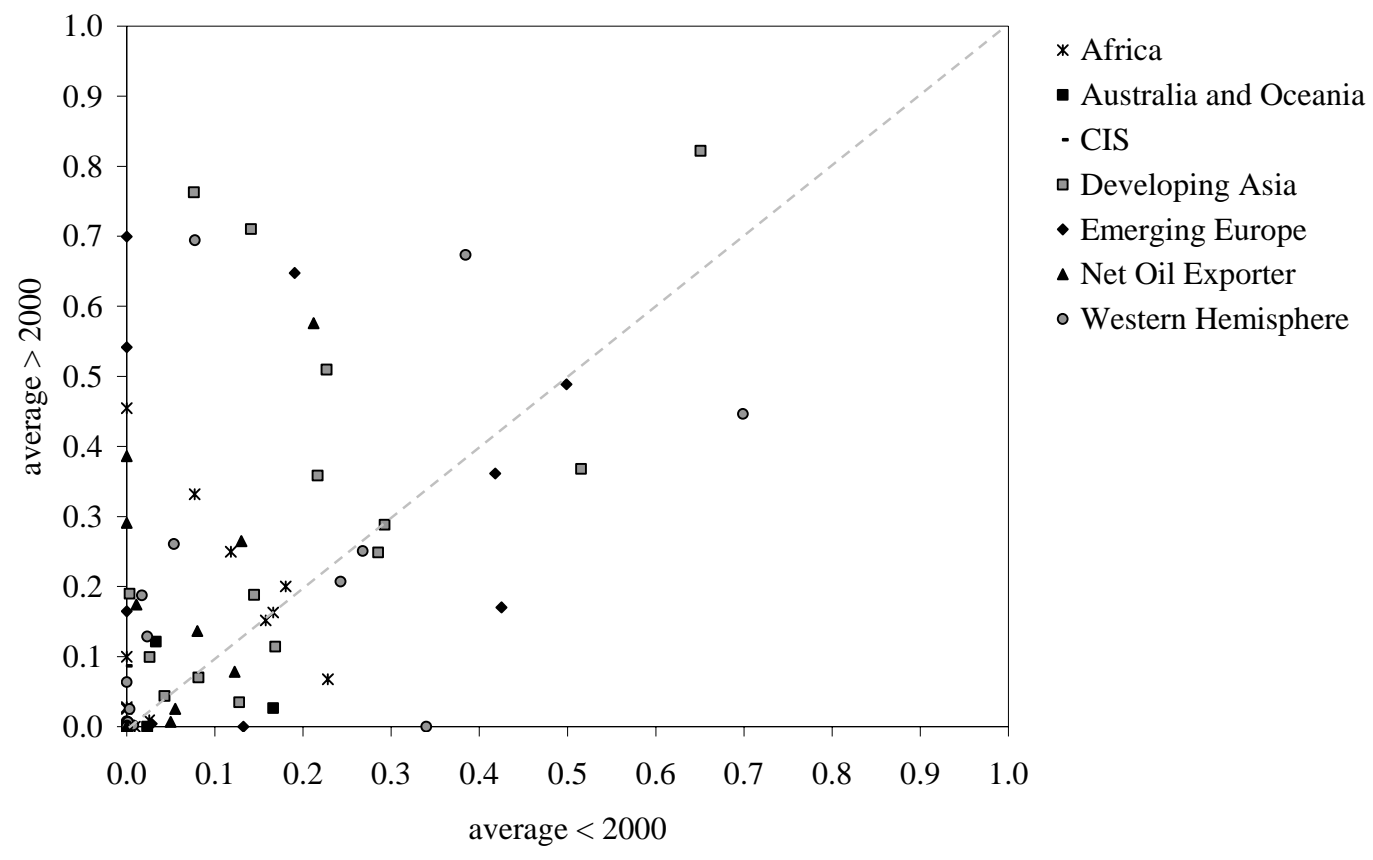

Source: IFS, National Central Banks.

10 It cannot be excluded that some of these operations are not market-oriented, as in repressed financial systems commercial banks can be forced to buy central banks bonds with yields below markets rates. For this reason the shares indicated in Figure 3 should be regarded as upper limits. 
Figure 4: Share of Bank Deposits in the Total Financing Gap

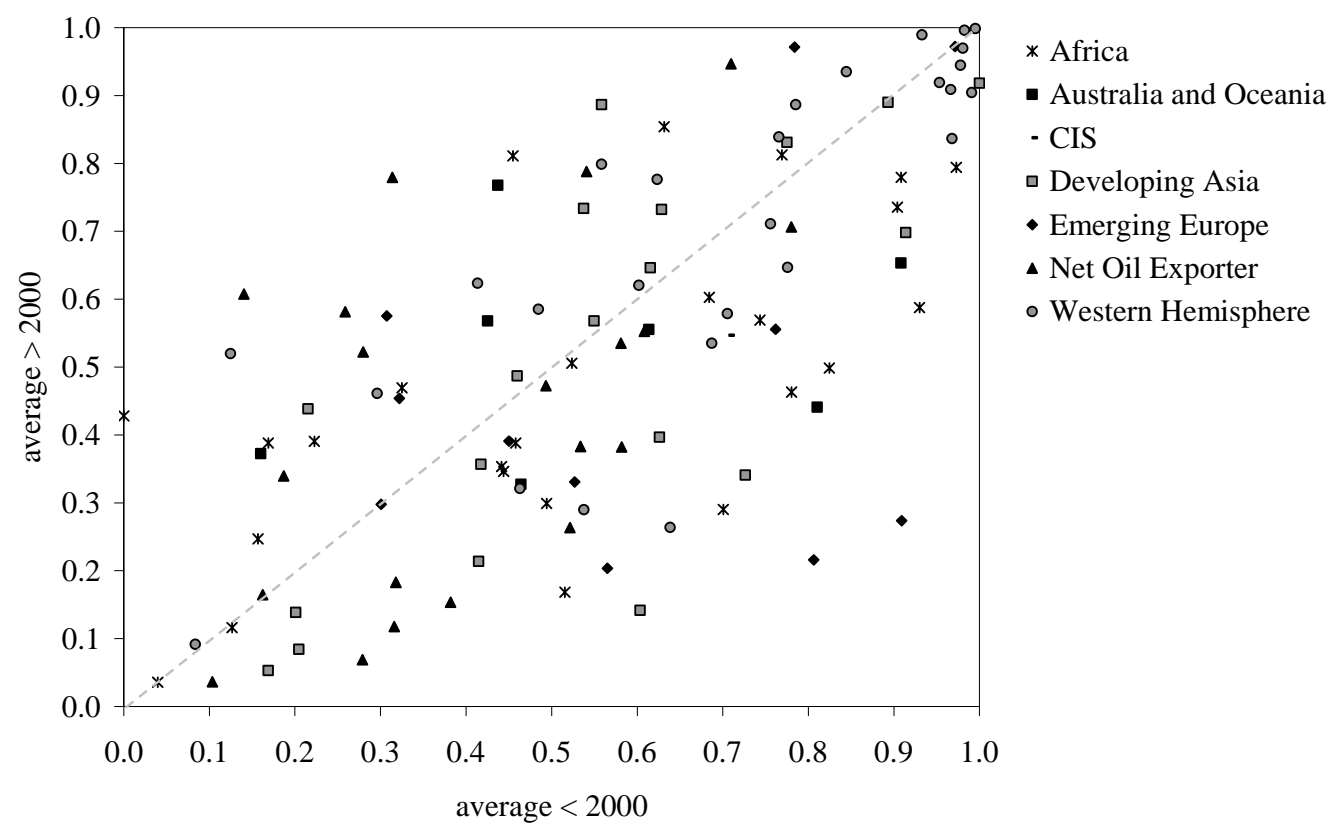

Source: IFS, National Central Banks.

In Figure 5 the share of government deposits in the total financing gap is shown as proxy for the size of liquidity absorbing operations that is coordinated with the fiscal authorities.

Figure 5: Share of Government Deposits in the Total Financing Gap

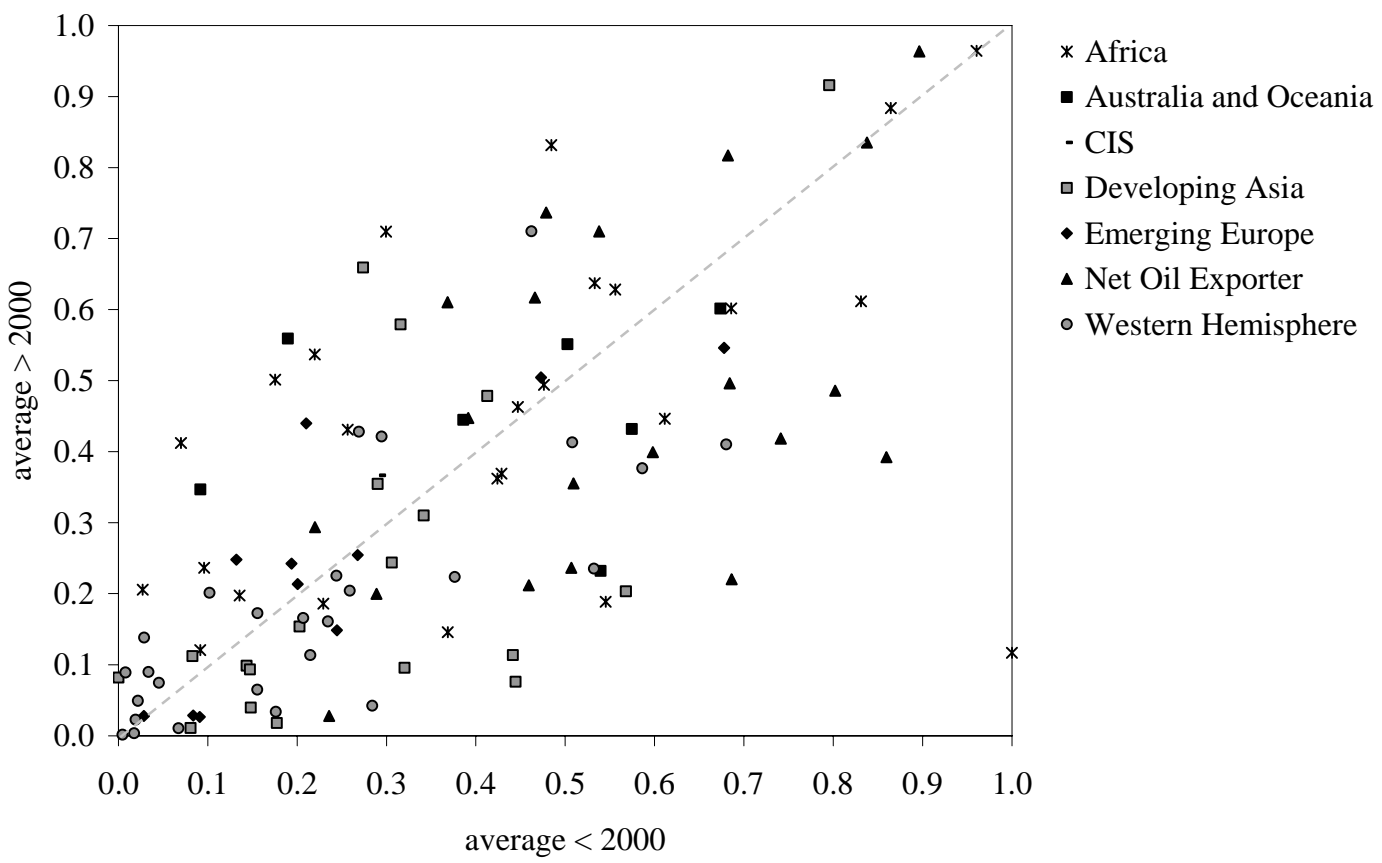

Source: IFS, National Central Banks. 
Government deposits are widely used as non-market oriented sterilization tools as indicated by the cluster around 50\%. The pattern has not changed significantly over time. The whole sample average of government deposits on the total financing gap decreased from 56 to 52 percent comparing the two observation periods. All in all, the relative importance of market and non-market based sterilization instruments used by debtor central banks seems to have remained widely constant over our observation period.

To provide first evidence on the liquidity position of economies that have introduced inflation targeting regimes we present in Table 2 the ratio of NFA/CIC for a sample of countries which have been identified as inflation targeters by Roger (2009). For reference we also include the euro area and US. As shown in Table 2, beside the US and euro area, all IT countries except UK and Canada are classified debtor central banks based on the NFA/CIC-ratio above unity.

\begin{tabular}{lcllll} 
Table 2: NFA/CIC of Inflation Targeting Countries Aug. 2009* & \\
\hline UK & 0.0 & Guatemala & 2.5 & New Zealand & 5.3 \\
Canada & 0.1 & Turkey & 2.5 & Peru & 5.4 \\
Australia & 1.1 & Hungary & 2.8 & Thailand & 6.0 \\
Ghana & 1.9 & Indonesia & 2.9 & Norway** & 6.9 \\
Czech Rep. & 2.0 & Philippines & 4.6 & Serbia & 9.5 \\
Mexico & 2.2 & South Africa & 4.6 & South Korea & 10.4 \\
Poland & 2.2 & Brazil & 4.8 & Iceland & 18.1 \\
Sweden & 2.2 & Israel & 4.9 & Euro Area & 0.1 \\
Colombia & 2.4 & Chile & 5.2 & US & 0.1 \\
\hline \hline
\end{tabular}

Source: IFS. *Or latest available data. ${ }^{* *}$ Government pension fund included.

The management of the surplus liquidity varies between the IT-countries. The Czech Republic and Hungary are central banks that conduct market-based sterilization operations as EU membership has fostered market-oriented principles for the implementation of monetary policy. In the Czech Republic, for example, sterilization costs have been quite high in earlier years when the interest differential to the euro area was large and positive. Later, valuation losses of foreign reserves (see section 4) have been dominant as the Czech koruna has tended to appreciate against the euro. ${ }^{11}$ In contrast, the Bank of Israel has coordinated its liquidity absorbing operations with the fiscal authorities (Schnabl and Schobert 2008). So called

\footnotetext{
${ }^{11}$ For instance, accumulated losses at the Czech National Bank reached half of the size of banknotes in circulation (Schobert 2008).
} 
makam are sold by the government to the Bank of Israel and from the Bank of Israel to the public for sterilization purposes. The respective revenues are held at so called makam deposits at the central bank. The high NFA-CIC ratio for Norway originates in a large investment portfolio from dollar denominated petroleum revenues. Its liquidity effect is contained via high government deposits at the central bank.

All in all, Table 2 shows that most central banks, which adopted IT frameworks have not succeeded to escape from the debtor central bank status. Only the Bank of England and the Bank of Canada are classified as creditor central banks according to our criterion - similar to Eurosystem and the Federal Reserve System.

Sterilization can take place in different ways as discussed above, and sterilization will be most costly for the central bank, if it is conducted in a market oriented way. The profit or loss of a debtor central banks, that only sterilizes in a market oriented way, consists of three main parts: (1) seigniorage, defined as the income from foreign reserves which is the counterpart of interest-free base money, i.e. CIC times the foreign interest rate, (2) sterilization costs in its narrow sense, i.e. the difference between NFA and CIC times the spread between the foreign and the domestic interest rate and (3) valuation changes of foreign reserves, i.e. NFA times changes of the nominal exchange rate. (1) und (2) can be seen as sterilization costs in a wider sense, as calculated in Figure 6. The (3), i.e. losses due to exchange rate changes will be discussed in section 3.2 .

Sterilization costs which would have occurred if IT debtor central banks had sterilized solely in a market oriented way are approximated in Figure 6. They are shown as a ratio to GDP and accumulated since the introduction of IT until 2007 (thus, excluding the crisis period 20082009). ${ }^{12}$ We make the following assumptions on the return on foreign reserves and the expenses on sterilization instruments: Without information on the currency composition, we generally assume that foreign assets are held in US treasury bills with one year maturity. ${ }^{13}$ For countries, which disclose the currency composition of foreign reserves, we use a weighted

12 The sterilization costs are approximated for parsimony reasons based on the financial gap and not based on the total financing gap as this would require information regarding the interest earned on domestic assets. If it is assumed that the interest earned on domestic assets is the same as paid on sterilization debt, the sterilization costs referring to the NFA financing gap are equal to the sterilization costs referring to the total financing gap.

${ }^{13}$ For Hungary and Serbia, however, we assume only euro-denominated foreign reserves. For the Czech Rep. we use US and euro bond yields $(33,66)$, for Poland US, euro and UK bond yields $(50,40,10)$, for Sweden US, euro, UK, Canadian and Australian bond yields (30, 50, 10, 5, 5). 
average of the respective government bond yields. Sterilization instruments are assumed to be remunerated at the domestic money market rates.

Figure 6: Cumulated Sterilization Costs from the Start of IT to 2007

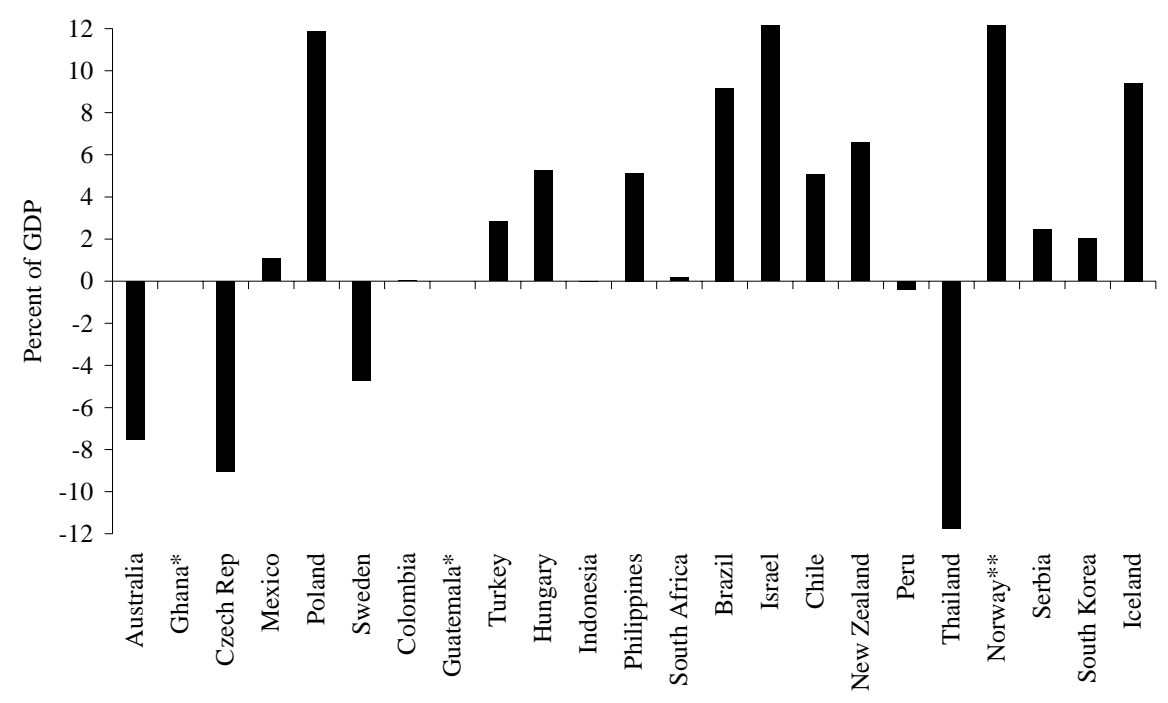

Source: IFS, National Central Banks. * No data available. ** Government pension fund included and assumed that fund deposits are remunerated at domestic market rates.

Figure 6 yield a heterogeneous picture. Australia, which is at the borderline to be a creditor central bank, tends to have a positive net income from monetary policy operations. In contrast, in particular the sterilization costs of Poland, Turkey, Israel, Norway, Serbia and Iceland seem to have been substantial since the introduction of the inflation targeting frameworks.

As shown in Appendix A most emerging market inflation targeting countries have also tended to miss their targets and to exhibit a higher volatility of inflation rates than the benchmark creditor central banks. If the sterilization costs are permanent as it is indicated in Appendix B this can influence the central bank behavior and the IT-performance as will be shown theoretically below.

\section{The Impact of Sterilization on Inflation: An Augmented Barro-Gordon Approach}

If an debtor central bank acts in accordance with the principles of an open market economy, it will introduce market-oriented sterilization operations together with an IT strategy and it will choose interest rates as the operational target. As the liquidity-absorbing operations compete 
with other investment opportunities and as domestic investment opportunities usually carry a higher interest rate than the investment in safe and liquid foreign reserves, the spread between interest earned on central bank assets and interest paid on sterilization debt is usually negative. Additionally, the strong accumulation of foreign reserves makes the central bank vulnerable to currency risk, when the IT strategy puts the focus on internal price stability and floating exchange rates. Thus, inflation targeting can incur additional costs for debtor central banks in comparison to creditor central banks, which can erode the capital, the reputation and (eventually) independence (Schobert 2008). Thus, central bank losses can be important (while central banks usually do not care about profits) and the goal of maintaining price stability can be traded off against saving these costs. By saving these costs and allowing for higher inflation, inflation expectations become more difficult to be anchored as highlighted below. ${ }^{14}$

\subsection{Market Based Sterilization}

In the baseline model we assume that the debtor central bank fully sterilizes in a market oriented way and that there are sterilization costs due to higher domestic interest rates compared to foreign interest rates. Furthermore, we assume that at the time of the introduction of the IT strategy the emerging market economy has high inflation and the central bank aims to disinflate.

\section{Liquidity Absorption and Inflation}

To analyze the inflation outcome of a debtor central bank, the baseline model of discretionary monetary policy developed by Kydland and Prescott (1977) and Barro and Gordon (1983a, 1983b) is augmented. ${ }^{15}$ The central bank decides in addition to optimal inflation and output on the optimal sterilization degree within an environment of surplus liquidity. For this reason sterilization costs are added to the central bank loss function.

Figure 7 visualizes the assumptions of the model based on a stylized central bank balance sheet: With currency in circulation assumed constant, the accumulation of foreign (NFA) and

\footnotetext{
${ }^{14}$ Gosselin (2007) finds that central bank transparency is negatively correlated with IT-performance. Section 3.1 provides a theoretical explanation for this finding: High-transparency reveals the trade-off between lowering inflation and incurring the risk of central bank losses in the case of debtor central banks. Lowering inflation in a market-oriented way can be very costly and can therefore contribute to higher inflation (expectations).

${ }^{15}$ We refer to the version of a quadratic central bank loss function described in Walsh (2001: 331-336).
} 
domestic assets (DA) has to be matched either through liquidity creation which is the increase in excess reserves $(\mathrm{X})$ or interest bearing sterilization instruments $(\mathrm{S}){ }^{16}$

Figure 7: Monetary Policy on the Liability Side

\begin{tabular}{|l|l|}
\hline Assets & Liabilities \\
\hline NFA & CIC \\
\cline { 2 - 2 } & Excess Reserves (X) \\
\cline { 2 - 2 } & Sterilization Debt (S) \\
\hline DA & \\
\hline
\end{tabular}

As rising (unremunerated) excess reserves can lead to excessive credit growth and thereby inflation, the central bank decides on the amount of (remunerated) sterilization debt depending on its inflation target.

Figure 8 shows the time sequence of the model. First, the central bank publishes an inflation target. Second, the public expects inflation based on rational expectations. Third, a supply shock occurs. Fourth, the central bank realizes inflation by choosing the degree of sterilization by setting the interest rate (which is assumed to be the policy instrument) on sterilization debt. Fifth, a demand shock occurs. ${ }^{17}$

\section{Figure 8: Game Sequence of the Underlying Model}

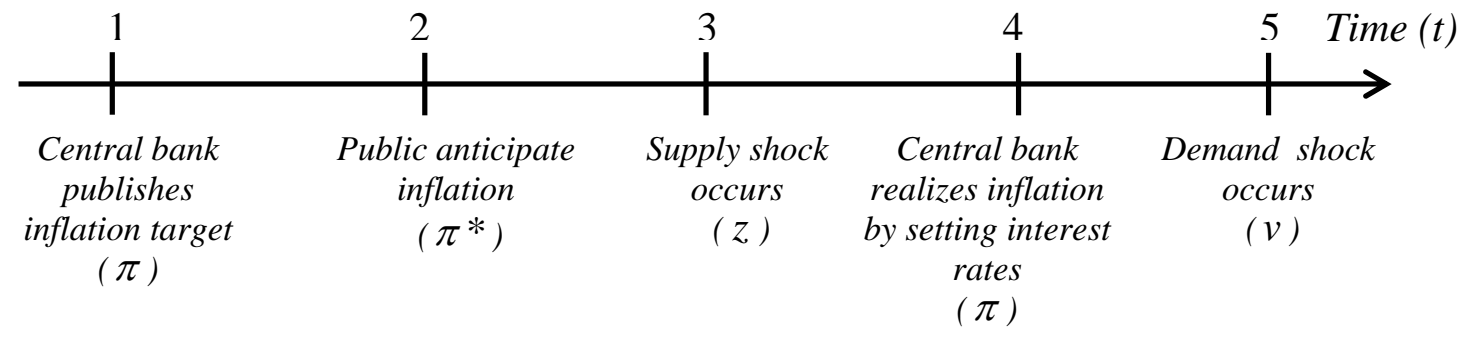

The central bank faces the following loss function $(L)$, which it seeks to minimize:

$$
L=\frac{1}{2} \lambda(y-\bar{y}-k)^{2}+\frac{1}{2}(\pi)^{2}+\gamma\left(i S-i_{f} N F A\right) .
$$

\footnotetext{
${ }^{16}$ In the following we denote variables in levels with upper case letters and variables in logs with lower case letters (except for the interest rate). An overbar indicates the long-term trend value.

${ }^{17}$ In contrast to an aggregate supply shock the outcome of an aggregate demand shock is symmetric with respect to output and prices. Thus, there should be no role for a stabilizing monetary policy.
} 
The first component represents the output target with the weight $\frac{1}{2} \lambda$ in which $y$ is the actual output, $\bar{y}$ is the policy independent (natural) output and $k$ is the output distortion. The central bank aims at stabilizing output around $\bar{y}+k$.

Actual output $y$ is given by the following Lucas-type aggregate supply function:

$$
y=\bar{y}+a\left(\pi-\pi^{*}\right)+z .
$$

The actual output increases in dependence on $a$, which quantifies the scope of surprise inflation on output. $\pi$ is the realized inflation and $\pi^{*}$ is the inflation anticipated by the public in $t-1$ for $t$. The term $z$ is a normal distributed supply shock with an expected value of zero and a finite variance

(3) $\quad z \sim N\left(0, \sigma_{z}^{2}\right)$.

The second component of (1) refers to the inflation target, which is assumed for parsimony to be zero. An inflation rate below or above zero implies a loss for the central bank. The third term reflects sterilization costs in a wide sense as specified in section 2.3. It therefore includes interest expenses on sterilization instruments with $S$ denoting the amount of outstanding market-based sterilization debt and $i$ the interest rate paid on sterilization instruments, which are offset by the interest income from the stock of NFA, which is the foreign interest rate $i_{f}$ times NFA. The factor $\gamma$ is the weight of sterilization costs in the central bank loss function.

Inflation in $t$ is linked to the central banks' policy instrument, the interest rate.

(4) $\pi=\pi_{\text {pre }}-\phi i+v$,

where $\pi_{\text {pre }}$ is the inflation prior to the adoption of IT, $i$ is the policy rate of the central bank with $\phi$ denoting the semi elasticity of prices to the policy rate. The negative sign implies falling (rising) inflation in times of interest rate increases (cuts). The term $v$ is a normal distributed demand shock influencing final inflation with an expected value of zero and a finite variance. An interest rate increase leads to lower inflation.

(5) $\quad v \sim N\left(0, \sigma_{v}^{2}\right)$. 
By substituting (2) and (4) into (1) and assuming that the central bank acts before observing the demand shock (see Figure 8), the central bank seeks to minimize the following expected loss function:

$$
E(L)=\frac{1}{2} \lambda\left(a\left(\pi_{p r e}-\phi i+v-\pi^{*}\right)+z-k\right)^{2}+\frac{1}{2}\left(\pi_{p r e}-\phi i+v\right)^{2}+\gamma\left(i S-i_{f} N F A\right) .
$$

Minimizing (6) with respect to $i$ yields the following optimal interest rate:

$$
i=\frac{\phi\left(\pi_{p r e}+\lambda a^{2}\left(\pi_{p r e}-\pi^{*}\right)-\lambda a(k+z)\right)-\gamma S}{\phi^{2}\left(1+\lambda a^{2}\right)}
$$

Because the public is assumed to be rational and to understand the incentives of the central bank and forms inflation expectations prior to the supply shock it holds: $\pi^{*}=E(\pi)=E\left(\pi_{\text {pre }}-\phi i+v\right)$. However, they do not take into account that their choice of expected inflation might have an impact on the central bank's decision. With expectations formed prior to observing the supply shock z, (4) and (7) imply, after solving for expected inflation

(8) $\pi^{*}=\lambda a k+\frac{\gamma S}{\phi}$.

With (8) into (7) und using (4) gives an expression for the equilibrium rate of inflation.

(9) $\pi=\lambda a k+\frac{\gamma S}{\phi}+\lambda a z+v$.

Equation (9) shows the equilibrium inflation rate under discretion in the case of a debtor central bank. With the inflation target being assumed zero, there is an inflation bias ( $\lambda a k)$ as in the case of creditor central banks (see Walsh 2001: 332): Average inflation rises with the weight of the output objective $\lambda$, the desired output expansion $k$ and the slope of the aggregate supply function $a$, which is the effect of surprise inflation on output. In contrast to the creditor central bank standard model average inflation in the debtor central bank case rises additionally by $\gamma S$ / $\phi$ which is the amount of the interest-bearing sterilization instrument $S$ weighted by the relevance of the sterilization costs for the central bank $\gamma$ divided by the semi interest rate elasticity of prices.

By substituting (9) and (8) into (2) it can be shown that on average actual output is equal to trend output as in the case of a creditor central bank. 


$$
y=\bar{y}+a v-z
$$

As the private sector is assumed to completely anticipate the inflation incentive of the central bank, in equilibrium monetary policy is not able to create a positive output effect through inflation.

In the underlying model the higher inflation bias of the debtor central bank compared to the creditor central bank is not a result from a dual objective of the central bank (targeting both the exchange rate and inflation). The inflation bias is higher because the central bank holds interest bearing sterilization instruments. Thus, as long as emerging market economies face surplus liquidity within the banking sector and manage it in a market oriented way, the central bank will have an incentive to allow for higher inflation compared to a central bank which is in a creditor position against the banking sector.

\subsection{Non-Market Based Sterilization}

Referring to equation (9) the extra inflation bias $\left(\pi^{+}\right)$of a debtor central bank relative to a creditor central bank is

$$
\pi^{+}=\pi_{\text {debtor }}-\pi_{\text {creditor }}=\frac{\gamma S}{\phi} .
$$

The central bank can force commercial banks to hold low or non-remunerated sterilization instruments which would shift the sterilization costs to the banking sector. The share of market-oriented sterilization instruments decreases, which is expressed in a lower $S$ in equation (9). If $S$ is repressed to zero the extra inflation bias $\left(\pi^{+}\right)$diminishes. The downside of sterilization through coercion can be seen in the macroeconomic outcomes. Depending on how commercial banks (are allowed to) deal with the sterilization tax, financial market disruptions such as disintermediation, diminished competitiveness with respect to foreign banking systems or higher spreads between lending and deposit rates emerge.

As financial markets are disrupted by the central bank intervention and the interest rate structure gets fragmented, inflation targeting via the interest rate channel is disturbed. ${ }^{18}$ In addition, as non-market based sterilization depresses interest rates in general, credit growth

18 A further segmentation of the banking system takes place if financial institutions are exposed to different degrees to non-market based sterilization instruments. 
and investment are boosted. The monetary authorities may feel urged to control credit growth and credit allocation directly. Beside the misallocating effects of credit ceilings (Lardy 2008) targeting broader monetary aggregates is not in line with an IT framework.

\subsection{Fiscal Coordination}

The additional inflation bias for debtor central banks in (11) would be also zero if $\gamma$ is zero. This is the case when the central bank gives up operational independence ${ }^{19}$ and asks the government to bear the sterilization burden as described in section 2.3.

As long as it is guaranteed that for monetary policy purposes the government functions as an agent of the central bank, institutional independence is not constrained and can be distinguished from operational independence. However, if a restrictive monetary policy increases the fiscal financing costs, the government may be inclined to limit the share of sterilization debt. Then it is likely that the government either shifts the sterilization efforts back to the central bank or urges the central bank to limit sterilization requests. The latter restrains the institutional independence of the central bank and erodes the efficiency of the inflation targeting as shown above.

If the sterilization dilemma is not transferred to the government (gamma is larger than zero) the central bank retains operational independence but sterilization costs matter. This again can endanger central bank independence if the central bank's equity is eroded and recapitalization of the central bank may become necessary.

Referring to Table 1 another form of fiscal coordination is shifting government deposits from the banking sector to the central bank. Then the sum of autonomous factors on the liability side of the balance sheet. The amount of outstanding sterilization debt $(S$ ) and thus the extra inflation bias of debtor central banks is reduced. This only holds if the government deposits at the central bank are not remunerated which stands for fiscal austerity and an incentive for the government to limit these accounts. In addition government deposits at the central bank may affect the continuity of monetary policy as the seasonal pattern of tax income and government expenditures is transferred via changing government deposits to monetary policy operations.

19 Operational independence requires that the central bank does not coordinate monetary policy instruments with the government. 
Uncertainty on the money market and in the banking system increases. If government deposits are altered rapidly and unpredictably the forecasting of autonomous factors and liquidity management becomes more difficult.

\section{Valuation Effects Via Domestic Currency Appreciation}

So far we have not addressed valuation effects of foreign reserves, which can arise from a change from an external to an internal monetary policy anchor. Valuation losses occur if buoyant capital inflows lead to a sustained appreciation pressure on the domestic currency. Whereas in practice sterilization costs account for almost half of central bank losses, valuation losses are the second most important factor for central bank losses (Schobert 2008). The immense foreign reserve holdings of many emerging market (debtor) central banks (Figure 1) indicate that the monetary authorities have leaned asymmetrically against exchange rate appreciation. Surrendering the exchange rate to the market would lead to an appreciation of the domestic currency, which implies a valuation loss of the net foreign assets.

Figure 9 shows the approximated average yearly valuation losses for our IT countries starting from the respective implementation of IT up to the end of 2007. The valuation losses are approximated by the cumulated quarterly losses, which are calculated as NFA times the quarter over quarter change of the respective exchange rate (against the US dollar, the euro, or a weighted average of other currencies depending on the currency composition of foreign reserves). The cumulated valuation losses are plotted together with sterilization costs as shown in Figure 8. In some countries average valuation losses are balanced out by sterilization costs. ${ }^{20}$ In many countries such as the Czech Republic, Poland, Hungary, Philippines, Norway, Serbia, South Korea and Iceland, the combined sterilization costs and valuation losses have exceeded the two percent of GDP per year. Only few countries such as Sweden or Hungary have realized gains.

20 In contrast to sterilization costs valuation losses are very volatile as shown in Appendix B. During the financial crisis most countries realized valuation gains due to depreciation. 
Figure 9: Cumulated Central Bank Losses from the Start of IT to 2007

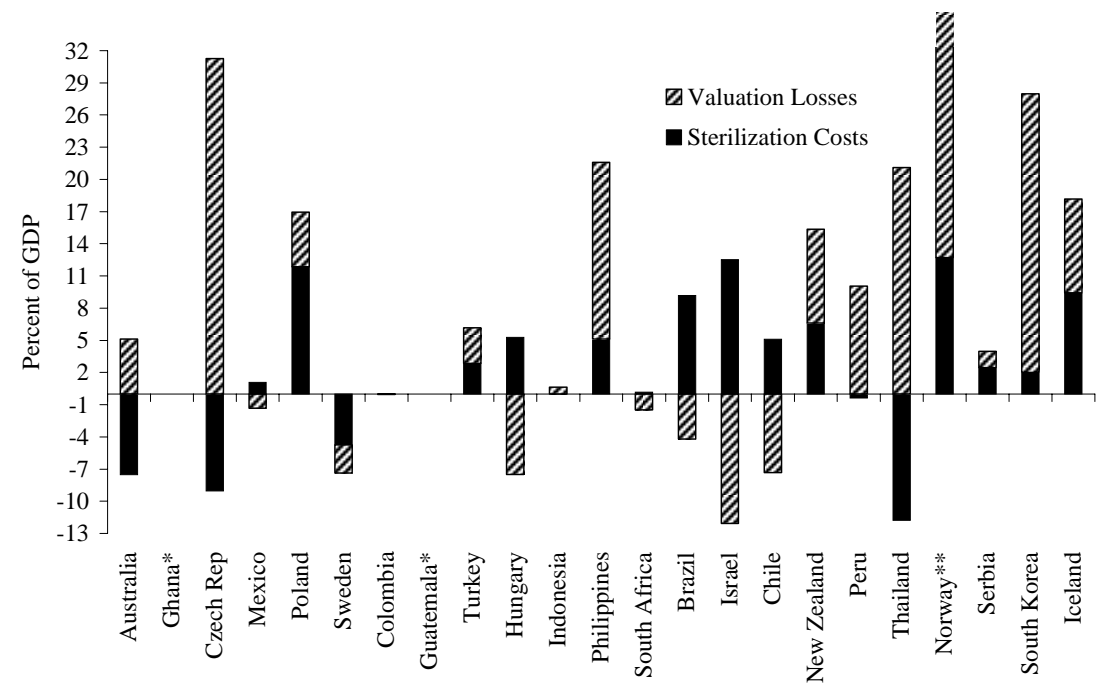

Source: IFS, National Central Banks. * No data available. ** Government pension fund included and assumed that fund deposits are remunerated at domestic money market rates. The valuation losses of the fund account for 134.5 percent of GDP.

Including valuation losses in the central bank loss function (1) provides the following objective function:

$$
L=\frac{1}{2} \lambda(y-\bar{y}-k)^{2}+\frac{1}{2}(\pi)^{2}+\gamma\left(i S-i_{f} N F A\right)-\hat{e}(N F A),
$$

The term $\hat{e}$ denotes the change of the spot exchange rate in price notation against the anchor country. In the case of appreciation of the domestic currency, the negative term turns positive increasing the loss of the central bank. The exchange rate is assumed to be determined by the relative purchasing power parity with $\beta$ as the degree of freedom to deviate from the absolute purchasing power parity and a factor $\xi$, which reflects the trend appreciation of the exchange rate. For simplicity the foreign inflation rate is assumed to be zero. This implies:

$$
\hat{e}=\beta \pi-\xi,
$$

Substituting (4) and (13) in (12) optimizing with respect to $i$ and following the arithmetic execution of section 3.1, equilibrium inflation is

$$
\pi=\lambda a k+\frac{\gamma S}{\phi}+\beta N F A+\lambda a z+v
$$

The extra inflation bias of debtor central banks originating in the appreciation of the domestic currency further increases with the stock of NFA and the factor $\beta$. Alternatively to (13) which models exchange rate changes based on relative price changes the incentive to ease 
sterilization efforts and thus allowing for higher inflation in the face of appreciation pressure can be derived from the financial account. Liquidity expansion resulting from reserve accumulation leads to interest rate cuts which slow down capital inflows (stimulate capital outflows) and thus reduce appreciation pressure and the exchange rate induced valuation losses.

Whereas sterilization losses can be reduced through non-market based measures at the expense of macroeconomic misalignments, valuation losses are more difficult to circumvent under inflation targeting regimes. Therefore, unslaving from the external monetary anchor based on IT frameworks is not a free lunch as the currency mismatch in central bank balance sheets becomes visible in form of realized losses.

\section{Conclusion}

A necessary condition to achieve an announced inflation target is to successfully anchor inflation expectations. In this regard, according to Mishkin (2004) two elements of an IT framework are important. First, an explicit quantitative target for inflation and, second, the accountability in achieving this inflation target, mainly through a transparent monetary policy strategy and implementation.

For a central bank, which conducts monetary policy within an environment of surplus liquidity both conditions are more difficult to achieve. We have shown that surplus liquidity due to the accumulation of foreign reserves is a worldwide phenomenon in emerging market economies. In this environment central bank losses due to sterilization costs and valuation losses are more likely, especially, if the central bank implements monetary policy in a market oriented way. Though central banks should focus on internal price stability within an IT framework, valuation losses and sterilization costs provide an incentive to respond to external targets in form of explicit or implicit exchange rate stabilization.

A high interest rate policy increases sterilization costs, attracts more capital inflows and triggers appreciation pressure on the exchange rate. Allowing for appreciation may help to achieve inflation targets (in particular when the interest rate channel is disturbed), but is restrained by the respective valuation losses. Given that central banks care about losses, we show that this makes it difficult to commit to a fixed quantitative inflation target and that this 
can explain why many central banks have pursued more "flexible forms" of inflation targeting, where inflation has remained above the announced target.

High transparency reveals the trade-off between lowering inflation and incurring the risk of central bank losses in the case of debtor central banks. Lowering inflation in a marketoriented way can be very costly and can therefore contribute to higher inflation expectations. From this perspective the success of implementing an IT framework depends not (as often assumed) on the distinction of high income or low-income countries, but on the liquidity position of the central bank against financial markets and the sterilization costs. In this context, exceptionally low world interest rates and the rapid foreign reserve accumulation in the last decade have challenged the success of inflation targeting in the case of debtor central banks.

Finally, the issue of central bank independence becomes even more important. To achieve low inflation and disregard the respective costs debtor central banks require a high degree of independence. Central bank statutes can either explicitly regulate losses via discretionary transfers from the government or require unconditional recapitalization. Alternatively, the central bank may keep the accumulated losses on its balance sheet and balance future profits with past losses, before profit distribution to the government resumes. How central banks ultimately deal with losses signals its de facto degree of independence. 


\section{References}

Ball, Laurence M./ Sheridan, Niamh 2005: Does inflation targeting matter? In: Bernanke, Ben, S./ Woodford, Michael (Eds.): The Inflation-Targeting Debate, University of Chicago Press.

Barro, Robert J./ Gordon, David B. 1983a: Rules, Discretion and Reputation in a Model of Monetary Policy, Journal of Monetary Economics 12, 101-121.

Barro, Robert J./ Gordon, David B. 1983b: A Positive Theory of Monetary Policy in a Natural Rate Model, Journal of Political Economy 91, 4, 589-610.

Bernanke, Ben S./ Laubach, Thomas/ Mishkin, Frederic S. / Posen, Adam S. 1999: Inflation Targeting: Lessons from the International Experience, Princeton University Press.

Bindseil, Ulrich 2005: Monetary Policy Implementation: Theory, Past and Present. Oxford University Press.

Calvo, Guillermo/ Mishkin, Frederic 2003: The Mirage of Exchange Rate Regimes for Emerging Market Countries, NBER Working Paper No. 9808.

European Central Bank 2001: The Liquidity Management of the ECB, Monthly Bulletin, July, 41-52.

Fischer, Stanley 2000: Foreign Exchange Regime: Is the Bipolar View Correct? The Finance and Development, June 2000.

Fraga, Arminio/ Goldfajn, Ilan/ Minella, Andre 2003: Inflation Targeting in Emerging Market Economies, NBER Working Paper 10019.

Gosselin, Marc-Andrew 2007: Central Bank Performance under Inflation Targeting, Bank of Canada Working Paper 18.

Kydland, Edward C./ Prescott, Finn E. 1977: Rules Rather Than Discretion: The Inconsistency of Optimal Plans, Journal of Political Economy 91, 4, 473-489.

Lardy, Nicholas R. 2008: Financial Repression in China, Peterson Institute for International Economics, September 8.

Leiderman, Leonardo/ Svensson, Lars E. 1995: Inflation Targets. Centre of Economic Polics Research, London.

McCallum, Bennett T. 1996: Inflation Targeting in Canada, New Zealand, Sweden, the United Kingdom, and in General, NBER Working Paper 5579.

McKinnon, Ronald 2004: The World Dollar Standard and Globalization: New Rules for the Game? in Michaelis, Leo/ Mark Lovewell (eds.), Exchange Rates, Economic Integration and the International Economy, APF Press, Toronto, 3-28. 
McKinnon, Ronald / Schnabl, Gunther 2009: China's Financial Conundrum and Global Imbalances. China and the World Economy 17 (2009), 1-32.

Mishkin, Frederic, 2004, “Can Inflation Targeting Work in Emerging Market Countries?” NBER Working Paper 10646.

Miskin, Frederic/ Schmidt-Hebbel, Klaus 2007: Does Inflation Targeting Make a Difference? In: Miskin, Frederic/ Schmidt-Hebbel, Klaus: Monetary Policy under Inflation Targeting, Banco Central de Chile, 291-372.

Roger, Scott 2009: Inflation Targeting at 20: Achievements and Challenges. IMF Working Paper, 236.

Rose, Andrew K. 2007: A Stable International Monetary System Emerges: Bretton Woods Reversed, Journal of International Money and Finance.

Schnabl, Gunther/ Schobert, Franziska 2009: Global Asymmetries in Monetary Policy Operations: Debtor Central Banks in the MENA Region. The Manchester School 77, 85-107.

Schobert, Franziska 2008: Why do Central Banks Make Losses, Central Banking, February, 79-83.

Schobert, Franziska 2006: Linking Financial Soundness and Independence of Central Banks Central and Eastern Europe, Turkey and CIS Countries. Review of International Business and Finance, 20, 2, 239-255.

Schobert, Franziska 2008: Why Do Central Banks Make Losses? Central Banking XVIII., 3.

Stella, Peter 2008: Central Bank Financial Strength, Policy Constraints and Inflation. IMF Working Paper, 49.

Svensson, Lars E. 1997: Inflation Forecast Targeting: Implementing and Monitoring Inflation Targets, European Economic Review 41, 1111-1146.

Walsh, Carl E. 2001: Monetary Theory and Policy, MIT Press, 321-336. 
Appendix A: Inflation Rates and Inflation Targets of Debtor Central Bank Countries (except US and Euro Area)

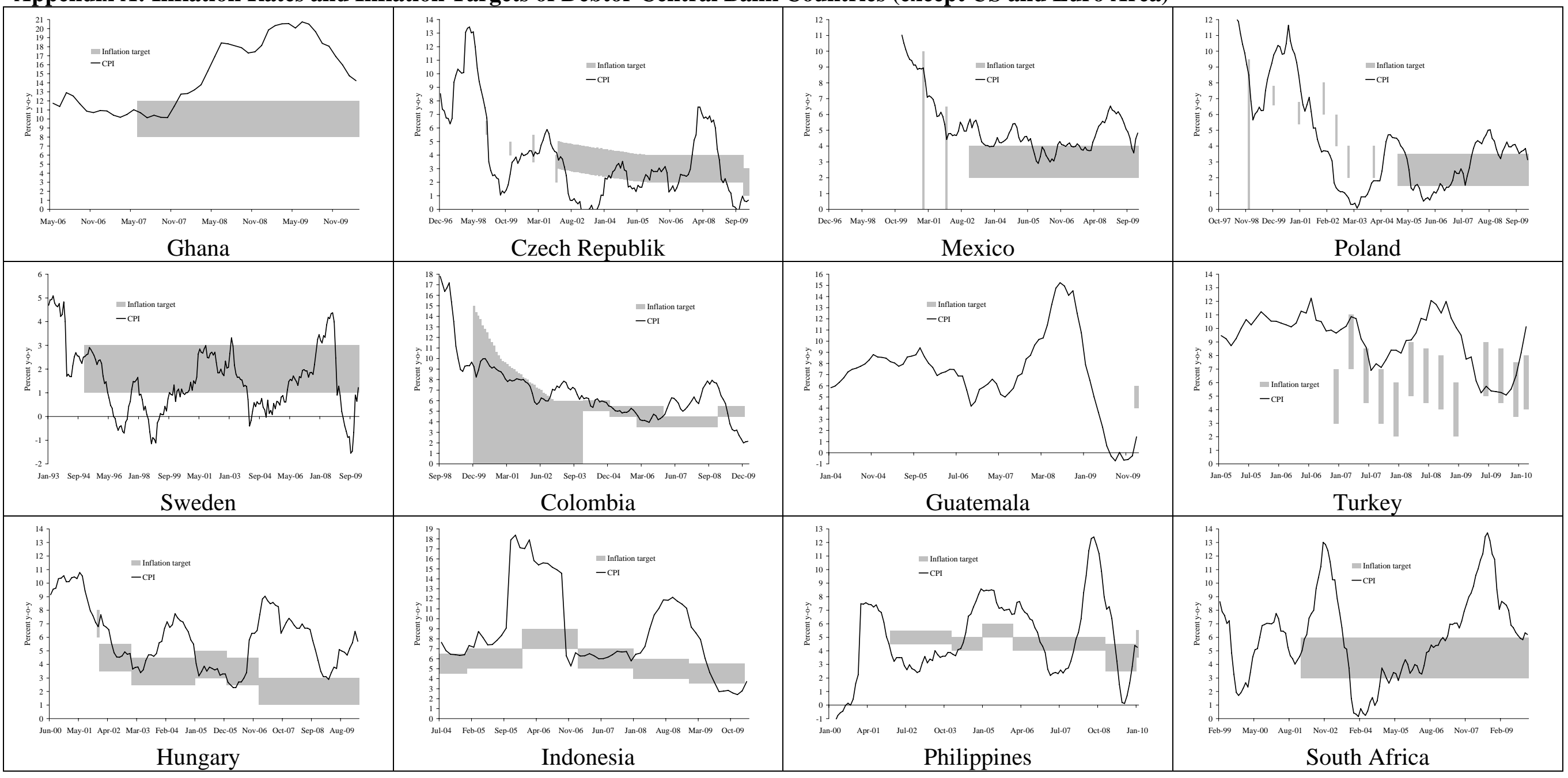




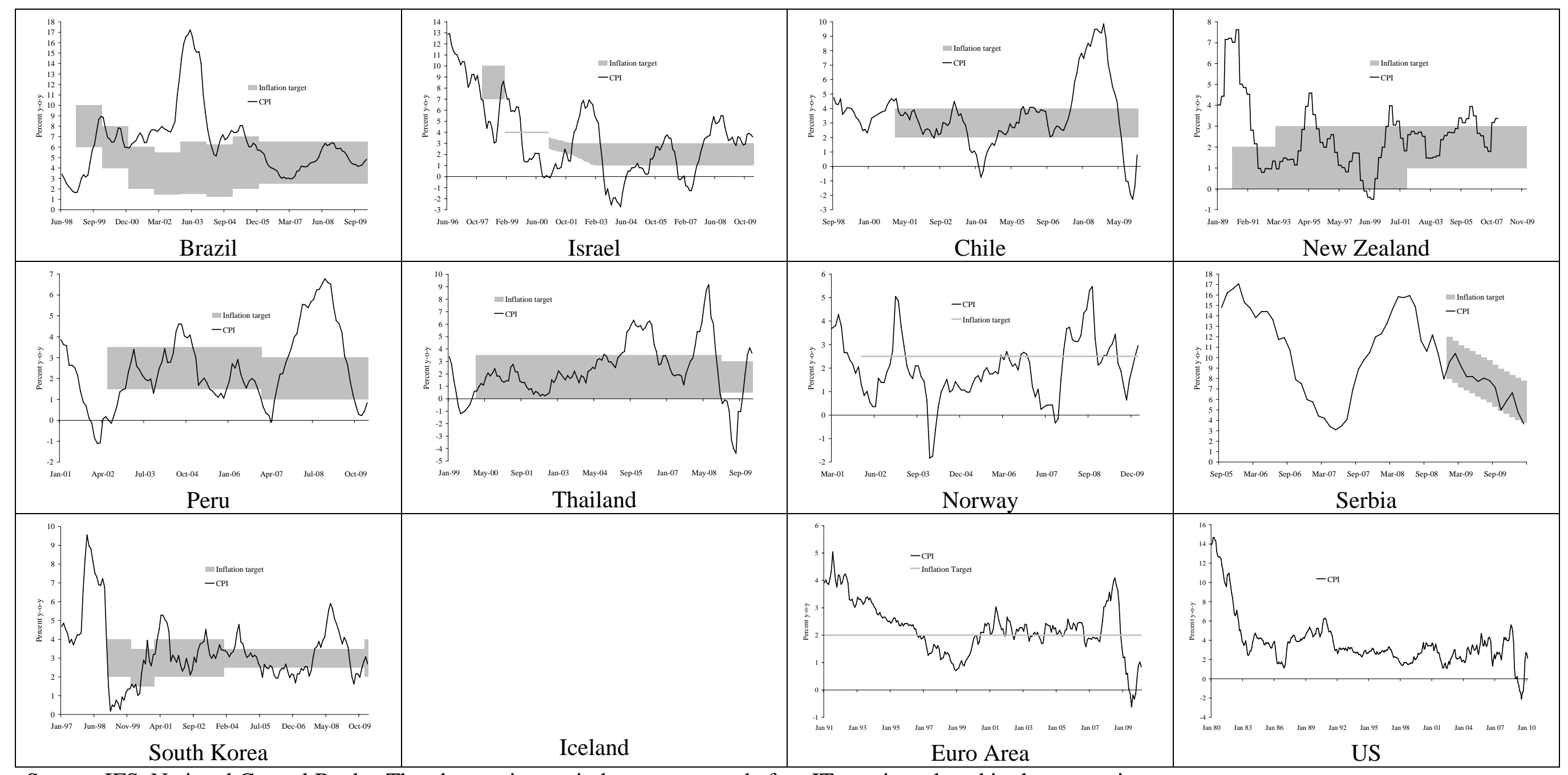

Source: IFS, National Central Banks. The observation period starts on year before IT was introduced in the respective country. 


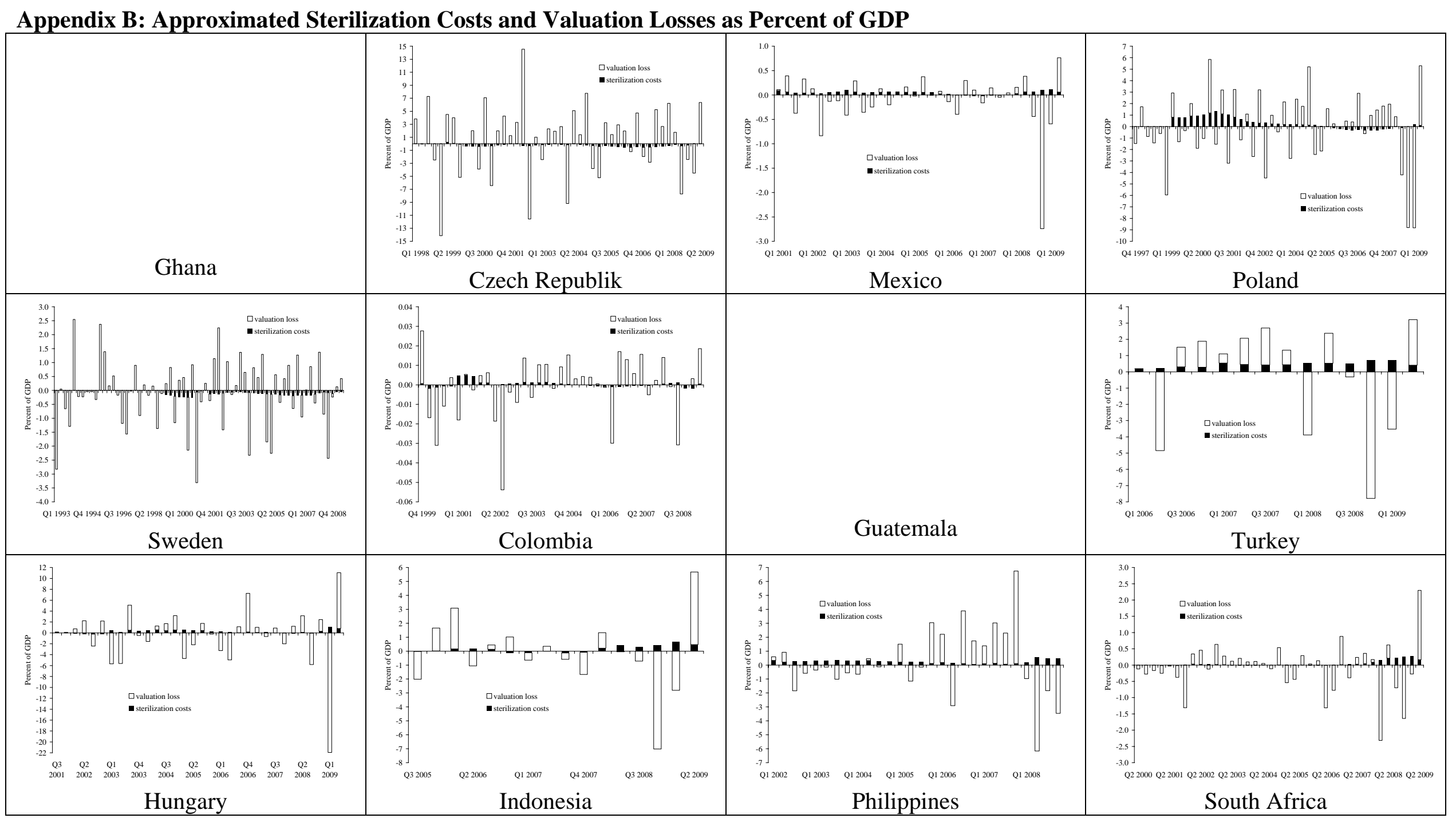




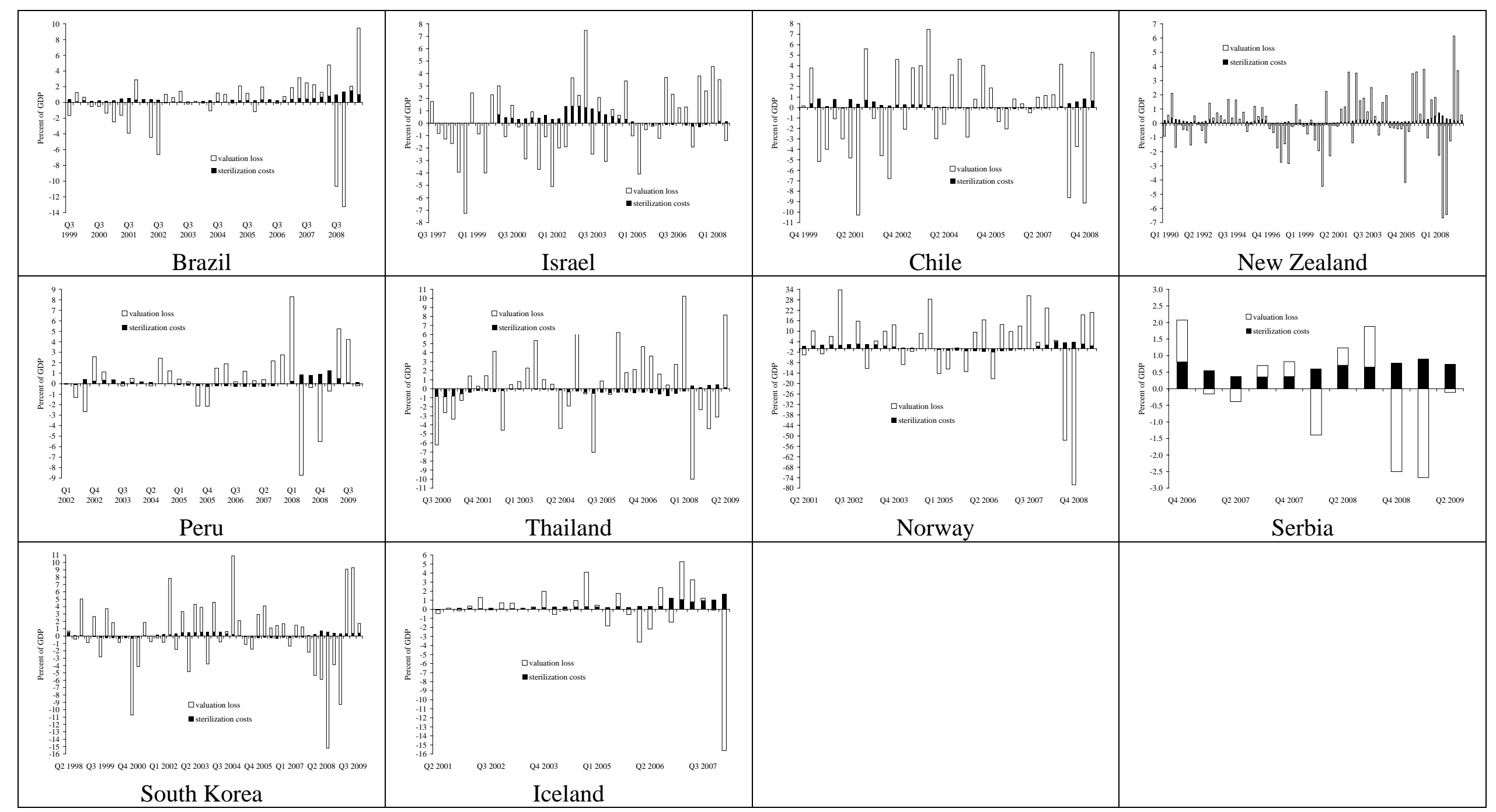

Source: IFS, National Central Banks. The observation period starts on year before IT was introduced in the respective country. 


\section{CESifo Working Paper Series}

for full list see www.cesifo-group.org/wp

(address: Poschingerstr. 5, 81679 Munich, Germany, office@cesifo.de)

3077 Alessandro Cigno, How to Deal with Covert Child Labour, and Give Children an Effective Education, in a Poor Developing Country: An Optimal Taxation Problem with Moral Hazard, June 2010

3078 Bruno S. Frey and Lasse Steiner, World Heritage List: Does it Make Sense?, June 2010

3079 Henning Bohn, The Economic Consequences of Rising U.S. Government Debt: Privileges at Risk, June 2010

3080 Rebeca Jiménez-Rodriguez, Amalia Morales-Zumaquero and Balázs Égert, The VARying Effect of Foreign Shocks in Central and Eastern Europe, June 2010

3081 Stephane Dees, M. Hashem Pesaran, L. Vanessa Smith and Ron P. Smith, Supply, Demand and Monetary Policy Shocks in a Multi-Country New Keynesian Model, June 2010

3082 Sara Amoroso, Peter Kort, Bertrand Melenberg, Joseph Plasmans and Mark Vancauteren, Firm Level Productivity under Imperfect Competition in Output and Labor Markets, June 2010

3083 Thomas Eichner and Rüdiger Pethig, International Carbon Emissions Trading and Strategic Incentives to Subsidize Green Energy, June 2010

3084 Henri Fraisse, Labour Disputes and the Game of Legal Representation, June 2010

3085 Andrzej Baniak and Peter Grajzl, Interjurisdictional Linkages and the Scope for Interventionist Legal Harmonization, June 2010

3086 Oliver Falck and Ludger Woessmann, School Competition and Students' Entrepreneurial Intentions: International Evidence Using Historical Catholic Roots of Private Schooling, June 2010

3087 Bernd Hayo and Stefan Voigt, Determinants of Constitutional Change: Why do Countries Change their Form of Government?, June 2010

3088 Momi Dahan and Michel Strawczynski, Fiscal Rules and Composition Bias in OECD Countries, June 2010

3089 Marcel Fratzscher and Julien Reynaud, IMF Surveillance and Financial Markets - A Political Economy Analysis, June 2010

3090 Michel Beine, Elisabetta Lodigiani and Robert Vermeulen, Remittances and Financial Openness, June 2010 
3091 Sebastian Kube and Christian Traxler, The Interaction of Legal and Social Norm Enforcement, June 2010

3092 Volker Grossmann, Thomas M. Steger and Timo Trimborn, Quantifying Optimal Growth Policy, June 2010

3093 Huw David Dixon, A Unified Framework for Using Micro-Data to Compare Dynamic Wage and Price Setting Models, June 2010

3094 Helmuth Cremer, Firouz Gahvari and Pierre Pestieau, Accidental Bequests: A Curse for the Rich and a Boon for the Poor, June 2010

3095 Frank Lichtenberg, The Contribution of Pharmaceutical Innovation to Longevity Growth in Germany and France, June 2010

3096 Simon P. Anderson, Øystein Foros and Hans Jarle Kind, Hotelling Competition with Multi-Purchasing: Time Magazine, Newsweek, or both?, June 2010

3097 Assar Lindbeck and Mats Persson, A Continuous Theory of Income Insurance, June 2010

3098 Thomas Moutos and Christos Tsitsikas, Whither Public Interest: The Case of Greece's Public Finance, June 2010

3099 Thomas Eichner and Thorsten Upmann, Labor Markets and Capital Tax Competition, June 2010

3100 Massimo Bordignon and Santino Piazza, Who do you Blame in Local Finance? An Analysis of Municipal Financing in Italy, June 2010

3101 Kyriakos C. Neanidis, Financial Dollarization and European Union Membership, June 2010

3102 Maela Giofré, Investor Protection and Foreign Stakeholders, June 2010

3103 Andrea F. Presbitero and Alberto Zazzaro, Competition and Relationship Lending: Friends or Foes?, June 2010

3104 Dan Anderberg and Yu Zhu, The Effect of Education on Martial Status and Partner Characteristics: Evidence from the UK, June 2010

3105 Hendrik Jürges, Eberhard Kruk and Steffen Reinhold, The Effect of Compulsory Schooling on Health - Evidence from Biomarkers, June 2010

3106 Alessandro Gambini and Alberto Zazzaro, Long-Lasting Bank Relationships and Growth of Firms, June 2010

3107 Jenny E. Ligthart and Gerard C. van der Meijden, Coordinated Tax-Tariff Reforms, Informality, and Welfare Distribution, June 2010 
3108 Vilen Lipatov and Alfons Weichenrieder, Optimal Income Taxation with Tax Competition, June 2010

3109 Malte Mosel, Competition, Imitation, and R\&D Productivity in a Growth Model with Sector-Specific Patent Protection, June 2010

3110 Balázs Égert, Catching-up and Inflation in Europe: Balassa-Samuelson, Engel's Law and other Culprits, June 2010

3111 Johannes Metzler and Ludger Woessmann, The Impact of Teacher Subject Knowledge on Student Achievement: Evidence from Within-Teacher Within-Student Variation, June 2010

3112 Leif Danziger, Uniform and Nonuniform Staggering of Wage Contracts, July 2010

3113 Wolfgang Buchholz and Wolfgang Peters, Equity as a Prerequisite for Stable Cooperation in a Public-Good Economy - The Core Revisited, July 2010

3114 Panu Poutvaara and Olli Ropponen, School Shootings and Student Performance, July 2010

3115 John Beirne, Guglielmo Maria Caporale and Nicola Spagnolo, Liquidity Risk, Credit Risk and the Overnight Interest Rate Spread: A Stochastic Volatility Modelling Approach, July 2010

3116 M. Hashem Pesaran, Predictability of Asset Returns and the Efficient Market Hypothesis, July 2010

3117 Dorothee Crayen, Christa Hainz and Christiane Ströh de Martínez, Remittances, Banking Status and the Usage of Insurance Schemes, July 2010

3118 Eric O'N. Fisher, Heckscher-Ohlin Theory when Countries have Different Technologies, July 2010

3119 Huw Dixon and Hervé Le Bihan, Generalized Taylor and Generalized Calvo Price and Wage-Setting: Micro Evidence with Macro Implications, July 2010

3120 Laszlo Goerke and Markus Pannenberg, 'Take it or Go to Court' - The Impact of Sec. 1a of the German Protection against Dismissal Act on Severance Payments -, July 2010

3121 Robert S. Chirinko and Daniel J. Wilson, Can Lower Tax Rates be Bought? Business Rent-Seeking and Tax Competition among U.S. States, July 2010

3122 Douglas Gollin and Christian Zimmermann, Global Climate Change and the Resurgence of Tropical Disease: An Economic Approach, July 2010

3123 Francesco Daveri and Maria Laura Parisi, Experience, Innovation and Productivity Empirical Evidence from Italy's Slowdown, July 2010 
3124 Carlo V. Fiorio and Massimo Florio, A Fair Price for Energy? Ownership versus Market Opening in the EU15, July 2010

3125 Frederick van der Ploeg, Natural Resources: Curse or Blessing?, July 2010

3126 Kaisa Kotakorpi and Panu Poutvaara, Pay for Politicians and Candidate Selection: An Empirical Analysis, July 2010

3127 Jun-ichi Itaya, Makoto Okamura and Chikara Yamaguchi, Partial Tax Coordination in a Repeated Game Setting, July 2010

3128 Volker Meier and Helmut Rainer, On the Optimality of Joint Taxation for NonCooperative Couples, July 2010

3129 Ryan Oprea, Keith Henwood and Daniel Friedman, Separating the Hawks from the Doves: Evidence from Continuous Time Laboratory Games, July 2010

3130 Mari Rege and Ingeborg F. Solli, The Impact of Paternity Leave on Long-term Father Involvement, July 2010

3131 Olaf Posch, Risk Premia in General Equilibrium, July 2010

3132 John Komlos and Marek Brabec, The Trend of BMI Values by Centiles of US Adults, Birth Cohorts 1882-1986, July 2010

3133 Emin Karagözoğlu and Arno Riedl, Information, Uncertainty, and Subjective Entitlements in Bargaining, July 2010

3134 John Boyd, Gianni De Nicolò and Elena Loukoianova, Banking Crises and Crisis Dating: Theory and Evidence, July 2010

3135 Michael R. Baye, Dan Kovenock and Casper G. de Vries, The Herodotus Paradox, July 2010

3136 Martin Kolmar and Hendrik Rommeswinkel, Group Contests with Complementarities in Efforts, July 2010

3137 Carolina Manzano and Xavier Vives, Public and Private Learning from Prices, Strategic Substitutability and Complementarity, and Equilibrium Multiplicity, July 2010

3138 Axel Löffler, Gunther Schnabl and Franziska Schobert, Inflation Targeting by Debtor Central Banks in Emerging Market Economies, July 2010 